\title{
PENGARUH MODEL PEMBELAJARAN INQUIRI TERBIMBING TERHADAP HASIL BELAJAR DAN KETERAMPILAN PROSES SAINS SISWA KELAS X SMA NEGERI TUGUMULYO TAHUN PEMBELAJARAN 2013/2014
}

\author{
Oleh
}

\author{
Surono $^{1}$, Lely Rosminarti ${ }^{2}$ \\ Program Study Pendidikan Fisika \\ FPMIPA STKIP PGRI Lubuk Linggau \\ surono.io@gmail.com
}

Tujuan penelitian ini adalah untuk mengetahui pengaruh model pembelajaran inquiri terbimbing terhadap hasil belajar dan mengetahui ketercapaian keterampilan proses sains fisika siswa dengan menggunakan model pembelajaran inquiri terbimbing di kelas X SMA Negeri Tugumulyo tahun pembelajaran 2013/2014. Jenis penelitian adalah eksperimen, dengan desain penelitian pre-test pos-test control group design. Populasi dalam penelitian ini adalah seluruh siswa kelas X SMA Negeri Tugumulyo. Dua kelas diambil sebagai sampel secara acak yaitu kelas X.2 sebagai kelas eksperimen dan kelas X.9 sebagai kelas kontrol. Teknik pengumpulan data menggunakan teknik tes dan observasi. Data skor tes siswa dianalisis dengan menggunakan uji $\mathrm{t}$ dan data observasi dianalisis secara deskriptif. Berdasarkan hasil analisis data post-test kelas eksperimen dan kelas kontrol dengan taraf signifikan $=0,05$ diperoleh bahwa $\mathrm{t}$ hitung $>\mathrm{t}$ tabel $(4,08>1,671)$, sehingga dapat disimpulkan bahwa ada pengaruh model pembelajaran Inquiri Terbimbing terhadap hasil belajar siswa di kelas X SMA Negeri Tugumulyo tahun pembelajaran 2013/2014. Dari analisis data keterampilan proses sains siswa diperoleh bahwa rata-rata keterampilan proses sains siswa adalah 75,26\% dengan kategori baik.

Kata Kunci : Inquiri Terbimbing, Hasil Belajar dan keterampilan proses sains.

\section{PENDAHULUAN}

Hasil belajar bidang sains di Indonesia masih belum memuaskan. Seperti yang dituliskan pada Kompas (kamis 5 Desember 2013) bahwa kemampuan anak Indonesia usia 15 tahun di bidang matematika, sains, dan membaca dibandingkan dengan anak-anak lain di dunia masih rendah. Hal ini mengacu pada hasil Programme for International Student Assessment 2012, Indonesia berada di peringkat ke-64 dari 65 negara yang berpartisipasi dalam tes.

Hal tersebut juga sejalan dengan hasil observasi awal, peneliti di SMA Negeri Tugumulyo tahun 2013/2014. Hasil evaluasi semester 1, menunjukkan bahwa siswa memperoleh nilai dibawah KKM 55\%, sedangkan siswa memperoleh nilai diatas KKM 45\%. Sehingga siswa yang tidak tuntas lebih banyak dari pada yang tuntas.

Masih rendahnya hasil belajar tersebut dipengaruhi oleh dua faktor yaitu faktor ekstrnal maupun internal. Seperti yang dikemukakan oleh Slameto (2010:54) bahwa faktor-faktor yang mempengaruhi hasil belajar dapat dibedakan menjadi dua jenis yaitu faktor internal (dari dalam) dan faktor eksternal (dari luar). Salah satu faktor eksternal adalah faktor sekolah, antara lain metode mengajar, kurikulum, relasi guru dengan siswa, disiplin sekolah, standar pelajaran di atas ukuran, serta penggunaan media gambar dalam penyampaian materi ajar.

Penentuan metode dan model pembelajaran yang sesuai dengan tujuan pembelajaran dan karakteristik materi sangatlah penting. Sebab dapat mempeharui ketercapaian tujuan pembelajaran.

Model pembelajaran inquiri terbimbing yaitu guru membimbing siswa melakukan kegiatan dengan memberi pertanyaan awal dan mengarahkan pada suatu diskusi. Guru mempunyai peran aktif 
dalam menentukan permasalahan dan METODE

tahap-tahap pemecahannya.

Menurut Sanjaya (2008:200), model pembelajaran inquiri terbimbing yaitu suatu model pembelajaran inquiri yang dalam pelaksanaannya guru menyediakan bimbingan atau petunjuk cukup luas kepada siswa. Sebagian perencanaannya dibuat oleh guru, siswa tidak merumuskan masalah.

Mengajarkan sains atau Fisika semestinya melibatkan keterampilan proses sains. Menurut Funk (dalam Dimyati dan Mudjiono, 2006:138-139) keterampilan proses sains memberikan kepada siswa pengertian yang tepat tentang hakikat ilmu pengetahuan. Dengan keterampilan proses sains berarti memberi kesempatan kepada siswa bekerja dengan ilmu pengetahuan, tidak sekedar menceritakan atau mendengarkan cerita tentang ilmu pengetahuan. Menggunakan keterampilan proses sains untuk mengajar ilmu pengetahuan, membuat siswa belajar proses dan produk ilmu pengetahuan sekaligus.

Keterampilan proses sains siswa merupakan keterampilan dalam pembelajaran yang mengarah kepada pengembangan kemampuan-kemampuan mental, fisik, dan sosial yang mendasar sebagai penggerak kemampuan yang lebih tinggi dalam diri individu siswa.

Namun pada kenyataannya pembelajaran sains ditingkat sekolah menengah masih di ajarkan secara konvensional. Ruslan (2012) menyatakan bahwa umumnya model dan metode pembelajaran yang diterap guru di sekolah menengah masih bersifat konvensional (ceramah, tanya jawab, demonstrasi) dan penugasan mengerjakan soal yang sesuai dengan contoh (Anwar; 2013:1).

Hasil belajar dan pembelajaran yang konvensional tersebut tentu tidak sesuai harapan dari Kurikulum 2013 yaitu kurikulum yang dapat menghasilkan insan Indonesia yang produktif, kreatif, inovatif, afektif melalui penguatan sikap, keterampilan, dan pengetahuan yang terintegrasi (permendikbud no.58 tahun 2014).
Desain penelitian yang digunakan yaitu Pretest-Posttest Control Group Design. Pada desain ini, kelas eksperimen diberi perlakuan dengan menggunakan model pembelajaran inquiri terbimbing sedangkan kelas kontrol diberikan perlakuan dengan menggunakan model pembelajaran konvensioanal yaitu metode ceramah dan tanya jawab. Data hasil belajar yang diperoleh melalui tes di uji normalitas dan homogenitasnya kemudian dilanjutkan dengan uji t. Untuk menguji kenormalan datanya digunakan persamaan;

$$
X^{2}=\Sigma \frac{\left(f_{0}-f_{h}\right)^{2}}{f_{h}}
$$

(Arikunto, 2010:333)

Dan untuk menguji homogenitasnya di gunakan persamaan;

$$
F=\frac{S_{1}^{2}}{S_{2}^{2}}
$$

(Sudjana, 2005:250)

Selanjutnya untuk mengetahui pengaruh model pembelajaran inquiri terbimbing terhadap hasil belajar dilakukan uji t dengan persamaan;

$$
t^{\prime}=\frac{\overline{\mathrm{X}_{1}}-\overline{\mathrm{X}_{2}}}{\sqrt{\frac{S_{1}^{2}}{\mathrm{n}_{1}}+\frac{S_{2}^{2}}{n_{2}}}}
$$

(Sudjana, 2005:239)

Data ketercapaian keterampilan proses sains diperoleh melalui observasi selama pembelajaran dan dianalisis secara deskriptif kualitatif yaitu dengan memberikan skor pada masing-masing aspek keterampilan porses sains yang dapat dicapai oleh siswa. Selanjutnya memberikan deskripsi skor pada masing-masing aspek keterampilan proses sains yang dapat dicapai. Adapun deskripsi kriteria berdasarkan persentase ketercapaian keterampilan proses sains yaitu; 
Tabel.1.Deskripsi kriteria ketercapaian keterampilan proses sains

\begin{tabular}{|c|l|l|}
\hline No & Skor $(\%)$ & Kriteria \\
\hline 1 & $75-100$ & Baik \\
\hline 2 & $50-74$ & Cukup \\
\hline 3 & $25-49$ & Kurang \\
\hline 4 & $0-24$ & Sangat Kurang \\
\hline
\end{tabular}

\section{HASIL DAN PEMBAHASAN}

Data hasil tes sebelum dilakukan uji $\mathrm{t}$, terlebih dahulu dilakukan uji normalitas dan uji homogenitas. Adapun hasil uji tersebut yaitu:

Tabel 2. Uji Normalitas

\begin{tabular}{|l|l|l|}
\hline Data & $\begin{array}{l}\text { Kelas } \\
\text { Eksperimen }\end{array}$ & $\begin{array}{l}\text { Kelas } \\
\text { Kontrol }\end{array}$ \\
\hline$X^{2}{ }_{\text {hitung }}$ & 9,04 & 4,37 \\
\hline$X_{\text {tabel }}$ & 11,07 & 11,07 \\
\hline Keterangan & $\begin{array}{l}\text { Berdistribusi } \\
\text { Normal }\end{array}$ & $\begin{array}{l}\text { Berdistribusi } \\
\text { Normal }\end{array}$ \\
\hline
\end{tabular}

Berdasarkan Tabel.2 dapat dikemukakan bahwa data hasil belajar berdistribusi normal. Demikian juga pada uji homogenitas diperoleh $\mathrm{F}_{\text {hitung }}<\mathrm{F}_{\text {tabel }}$ yaitu $\mathrm{F}$ hitung $=1,43$ dan $\mathrm{F}_{\text {tabel }}=1,69$, artinya kedua kelas tersebut homogen.

Tabel 3. Hasil Uji t

\begin{tabular}{|l|l|}
\hline Data & Nilai \\
\hline$t$ hitung & 4,08 \\
\hline$t$ tabel & 1,67 \\
\hline DK & 74 \\
\hline keterangan & t hitung $>\mathrm{t}$ tabel \\
\hline
\end{tabular}

Berdasarkan Tabel 3, dapat dikemukakan bahwa hasil uji analisis uji$\mathrm{t}$ mengenai kemampuan akhir siswa menunjukkan bahwa $t_{\text {hitung }}>t$ tabel yaitu $t$ hitung $=4,08$ dan $t_{\text {tabel }}=1,67$ berarti ratarata skor kelas eksperimen dan kelas kontrol adalah tidak sama. Dengan kata lain bahwa rata-rata nilai kelas eksperimen lebih besar daripada kelas kontrol dengan taraf kepercayaan $\alpha=0,05$, Berdasarkan analisis tersebut maka hipotesis pada penelitian ini yang berbunyi ada pengaruh model pembelajaran inquiri terbimbing terhadap hasil belajar siswa di kelas X SMA Negeri Tugumulyo tahun pembelajaran 2013/2014 telah terbukti.
Keterampilan proses sains diamati secara kelompok yang terdiri dari enam aspek penilaian yaitu merumuskan masalah, merumuskan hipotesis, pengamatan, pengukuran, menyimpulkan, dan mengkomunikasikan.

Tabel 4. Ketercapaian Keterampilan Proses Sains

\begin{tabular}{|c|l|l|l|}
\hline \multirow{2}{*}{ No } & \multicolumn{1}{|c|}{$\begin{array}{c}\text { Aspek } \\
\text { Keterampilan } \\
\text { proses sains }\end{array}$} & \multicolumn{2}{|c|}{$\begin{array}{c}\text { Persentase } \\
\text { ketercapaian }\end{array}$} \\
\cline { 3 - 4 } & $\begin{array}{c}\text { Observasi } \\
\text { ke-1 }\end{array}$ & $\begin{array}{c}\text { Observ } \\
\text { asi ke-2 }\end{array}$ \\
\hline 1 & $\begin{array}{l}\text { Merumuskan } \\
\text { masalah }\end{array}$ & 68,75 & 81,25 \\
\hline 2 & $\begin{array}{l}\text { Merumuskan } \\
\text { Hipotesis }\end{array}$ & 62,50 & 84,38 \\
\hline 3 & Pengamatan & 65,63 & 81,25 \\
\hline 4 & Pengukuran & 65,63 & 84,38 \\
\hline 5 & Penyimpulan & 62,50 & 84,38 \\
\hline 6 & $\begin{array}{l}\text { Mengkomunikasi } \\
\text { kan }\end{array}$ & 71,88 & 90,63 \\
\hline \multicolumn{2}{|l|}{ Rata-rata } & 66,88 & 84,38 \\
\hline \multicolumn{2}{|l|}{ Kategori } & Cukup & Baik \\
\hline
\end{tabular}

Berdasarkan Tabel 4, dapat dikemukakan bahwa pada pengamatan pertama aspek keterampilan proses sains rata-rata cukup baik. Pada pengamtan ke dua keterampilan proses sains dapat di capai dengan rata-rata baik. Dari data tersebut dapat simpulkan bahwa pembelajaran dengan model inquiri terbimbing dapat mendorong tercapainya keterampilan proses sains dalam proses pembelajaran. Dengan kata lain, bahwa dengan penerapan model inquiri terbimbing siswa terampil dalam menggunanakan keterampilan proses sains dalam pembelajaran. 


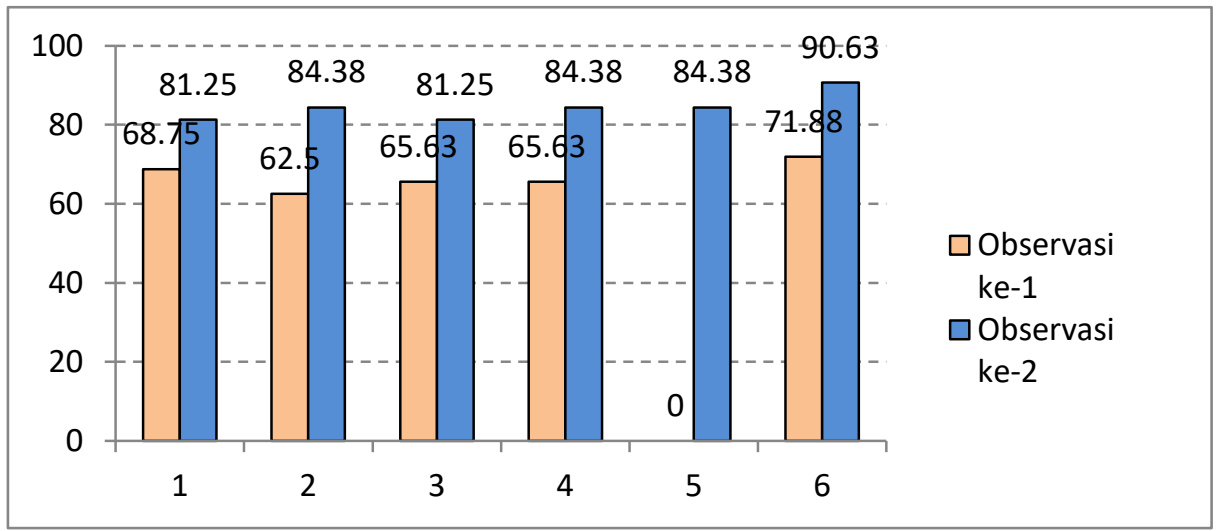

Gambar.1. Grafik ketercapaian keterampilan proses sains

Berdasarkan Gambar 1, dapat dikemukakan bahwa ketercapaian keterampilan proses sains yang paling besar adalah yang ke-6 yaitu mengkomunikasikan dengan presentasi ketercapaiannya 90,63. Dan keterampilan proses yang lain rata-rata tercapai dengan baik.

SIMPULAN

Berdasarkan hasil penelitian pengaruh model pembelajaran inquiri terbimbing terhadap hasil belajar maka

\section{DAFTAR PUSTAKA}

Anwar, Nurul Hakim Fikri. 2013.Profil Penguasaan Konsep Siswa SMA pada pembelajaran tumbukan efektif menggunakan metode discovery Inquiri.

Arikunto, Suharsimi. 2006. Prosedur Penelitian Suatu Pendekatan Praktek. Jakarta: Rineka Cipta.

Dimyati, Mudjiono. 2006. Belajar dan Pembelajaran. Jakarta : Rineka Cipta.

Giancoli. 2001. Fisika Edisi Kelima Jilid 2. Jakarta: Erlangga.

Hamalik, Oemar. 2001. Proses Belajar Mengajar. Bandung: Bumi Aksara.

Kemendikbud. 2013. Вuku Guru Ilmu Pengetahuan Alam. Jakarta: Kemendikbud. dapat disimpulkan bahwa ada pengaruh model pembelajaran inquiri terbimbing terhadap hasil belajar fisika siswa kelas $X$ SMA Negeri Tugumulyo tahun pembelajaran 2013/2014. Keterampilan proses sain dapat dicapai secara baik meliputi enam aspek yaitu merumuskan masalah, merumuskan hipotesis, pengamatan, pengukuran, menyimpulkan, dan mengkomunikasikan.

[www.repository.upi.edu/2539/4/S_KIM_06 01962_Chapter1.pdf.(diakses 11 November 2014

Kemendikbud. 2013. Materi Pelatihan Guru Implementasi kurikulum 2013. Jakarta: Kemendikbud.

Kompas (5 Desember 2013). Kemampuan Matematika dan Sains di Urutan Ke-64 dari 65 Negara. http://www.kopertis12.or.id/2013/12/05/skor -pisa-posisi-indonesia-nyaris-jadi-jurukunci.html. [diakses 10 November 2014]

Putra, Sitiatava Rizema. 2013. Desain Belajar Mengajar Kreatif Berbasis Sains. Jogjakarta: DIVA Press.

Rusman. 2012. Pembelajaran, Model-model Mengembangkan 
Profesionalisme Guru. Jakarta: Rajawali Pers.

Slameto. 2010. Belajar dan Faktor-faktor yang Mempengaruhnya. Jakarta: Rineka Cipta.

Sudjana. 2005. Metoda Statistika. Bandung: Tarsito.

Trianto. 2010. Mendesain Model Pembelajaran Inovatif-Progresif. Jakarta: Kencana. 